\title{
FORMULASI MODEL KADAR KOLESTEROL SERUM MELALUI PENDEKATAN UKURAN SKINFOLD PADA ORANG DEWASA
}

\author{
Ila Fadila (ila@mail.ut.ac.id) \\ Universitas Terbuka
}

\begin{abstract}
ABSTRAK
The study was conducted to explore the relationship between anthropometric measurement, i.e. skinfold thickness and cholesterol consentration in adult male and female blood. Other variables assumed as confounders including respondent characters namely: age, sex, ethnic, smoking habit, and activity. Analysis was done to a data from Health and Nutrition Survey on Adult on six cities in Indonesia. Prediction model of serum cholesterol with nutritional status assessment was developed by multiple regression analysis. Backward elimination procedure was used for model processing. The study result indicated that there was positive correlation between cholesterol and skinfold, age, and ethnic. Prediction model of serum cholesterol can be showed: Serum Cholesterol $=153,58+0,36$ Skinfold + 0,34 age $-1,46$ Sex $-48,71$ Activity $+27,84$ Ethnic
\end{abstract}

Key words: age, cholesterol, ethnic, skinfold.

Hasil Survei Kesehatan dan Rumah Tangga (SKRT) tahun 1986 dan 1992 menunjukkan ada kecenderungan naiknya penyebab kematian oleh penyakit sistem sirkulasi dari $9,95 \%$ menjadi 16,6\% dari seluruh kematian. Pada SKRT tahun 1995 penyakit sistem sirkulasi ini telah menduduki peringkat pertama pada masyarakat mulai usia 35 tahun ke atas (31\%). Hal ini terutama terjadi di daerah perkotaan. Penyakit sistem sirkulasi salah satu di antaranya adalah hiperkolesterolemia, yang juga merupakan salah satu faktor risiko penyakit jantung koroner.

Hiperkolestrolemia sebagai indikator tingginya kadar kolesterol serum, cara pengukurannya dapat didekati dengan penilaian status gizi. Penilaian status gizi dapat dilakukan dengan metode penilaian secara langsung yang meliputi empat cara yaitu klinis, tes biokimia, biofisik dan antropometri sedangkan secara tidak langsung antara lain melalui data tentang mortalitas dan morbiditas, hasil sensus, dan pengukuran melalui variabel ekologi bidang pangan dan non pangan.

Selama ini pengukuran kadar kolesterol serum lebih dikenal melalui pemeriksaan secara laboratoris. Namun demikian, karena memerlukan biaya yang tidak sedikit, pemeriksaan secara laboratoris sulit dijangkau oleh masyarakat umum. Sebagai solusinya, pengukuran secara antropomertri dikenalkan karena dianggap praktis dan murah.

Pengukuran kadar kolesterol serum ini diupayakan didekati melalui pengukuran antropometri dengan menilai lemak tubuh. Berdasarkan Tabel Durnin \& Womersley (Garn, 1991) yang termasuk overweight adalah mereka yang mempunyai persentase lemak tubuh $>20 \%$ untuk laki-laki dan $>30 \%$ untuk wanita, atau ukuran skinfold $60 \mathrm{~mm}$ untuk laki-laki dan $65 \mathrm{~mm}$ untuk wanita. Ukuran skinfold didasarkan pada penjumlahan empat bagian skinfold (triceps, biceps, suprailiac dan subscapular). 
Hubungan antara distribusi lemak terutama skinfold thickness dengan lipida darah masih belum banyak diteliti. Penelitian yang sudah mulai banyak dilakukan adalah hubungan antara distribusi lemak dengan total lemak tubuh. Penelitian Hakim, Amina, Mohammed, Nagwa, \& ElJusseiny (1997) melaporkan adanya hubungan yang bermakna antara pengukuran skinfold thickness (biceps, triceps, subscapular, suprailiac, femoral dan abdominal) dengan kadar lipida darah (total kolesterol, trigliserida) terutama pada bagian abdominal, subscapular dan suprailiac. Bersama dengan Indeks Massa Tubuh (IMT), rasio subscapular dan triceps, serta abdominal skinfold dapat menjelaskan ke dua kadar lipida darah (total kolesterol, trigliserida) sekitar 47,5\%. Hasil penelitian yang dilakukan oleh Garn (1991) menyatakan bahwa skinfold thickness meningkat sejalan dengan meningkatnya umur, begitu juga dengan kolesterol darah. Hubungan antara skinfold dan kolesterol darah tidak terlalu kuat yaitu sekitar 0,20-0,30. Hubungan skinfold thickness dengan trigliserida agak lebih tinggi, sementara itu hubungan dengan kolesterol HDL merupakan hubungan yang negatif.

Faktor yang berhubungan dengan kadar kolesterol serum adalah:

1. Umur dan jenis kelamin.

Pada perempuan maupun laki-laki, meningkatnya umur akan meningkatkan pula kadar kolesterol serum total. Pada umur 25 hingga 44 tahun tampaknya laki-laki mempunyai kadar kolesterol yang lebih tinggi dibandingkan perempuan, sebaliknya pada umur 45 tahun ke atas kadar kolesterol serum pada perempuan lebih tinggi dibandingkan laki-laki (Wynder, Field, \& Haley, 1986).

2. Sukubangsa.

Penelitian Clifton, Abbey, Noakes, \& Beltrame (1995) memperlihatkan bahwa kolesterol perempuan kulit hitam lebih rendah dibandingkan perempuan kulit putih, begitu juga dengan trigliserida, glukosa dan insulin. Namun sebaliknya dengan kolesterol HDL. Selanjutnya dibuktikan pula bahwa pada kelompok umur 20 - 23 tahun, orang Asia memliki kadar kolesterol lebih tinggi dibandingkan orang Eropa.

3. Aktivitas fisik.

Penelitian Cooper, Myers, Smith, \& Schlant (1992) membuktikan bahwa responden yang biasa melakukan kegiatan olah raga jalan $\geq 2,5$ jam/minggu ternyata kolesterol totalnya berkurang sekitar 3\% dan kolesterol HDL meningkat sebanyak 3,4\%.

4. Kebiasaan merokok.

Hasil studi Cooper et.al. (1992) menyatakan bahwa pada perokok sigaret usia dewasa memiliki kadar kolesterol lebih tinggi 3\% dari mereka yang tidak merokok. Begitu juga hasil temuan Seidell, Cigolini, Charzweska, \& Ellsinger (1990) melaporkan, bahwa pada mereka yang tergolong perokok memiliki kolesterol total dan insulin yang lebih tinggi dibandingkan dengan mereka yang tidak merokok.

5. Asupan makanan.

Dengan adanya penambahan asupan lemak, terdapat hubungan yang erat antara waist girth dan perubahan kolesterol HDL pada individu yang overweight, namun tidak demikian pada individu yang kurus terutama pada jenis kelamin wanita (Clifton et.al., 1995).

Penelitian ini dilakukan untuk mendapatkan model pendugaan kadar kolesterol serum dengan menggunakan ukuran antropometri melalui pendekatan pengukuran skinfold, variabel umur, jenis kelamin, indeks aktivitas, kebiasaan merokok, dan suku bangsa pada orang dewasa. 


\section{METODOLOGI}

Metode penelitian menggunakan desain cross sectional. Data sekunder diperoleh dari Survey Gizi dan Kesehatan pada Orang Dewasa (kerjasama Direktorat BGM Depkes RI dan FKM-UI) di enam ibukota propinsi: Medan, Padang, Bandung, Yogyakarta, Denpasar, dan Makassar. Populasi adalah orang dewasa yang berumur $\geq 18$ tahun. Kriteria responden yang diikutsertakan adalah: orang dewasa, tidak hamil, dan berbadan sehat. Proses pengambilan sampel data primer yang dilakukan oleh Depkes dan FKM-UI dilakukan dengan cara menggunakan rancangan sampel klaster dua tahap, yaitu: Probability Propotionate to Size (PPS) untuk memilih klaster (tahap I) dan Simple Random Sampling (SRS) untuk memilih rumah tangga (tahap II).

Pada tahap I dibuat daftar nama desa (kelurahan) dan jumlah penduduknya pada tiap kotamadya. Kemudian dari daftar ini dipilih secara acak sebanyak 30 klaster (bisa saja terambil pada 1 desa terdiri dari 1 atau 2 klaster). Kemudian dibuat daftar klaster terpilih berikut jumlah rumah tangga yang akan disurvei (1 klaster setara $7-10$ rumah tangga setara \pm 30 responden). Pada tahap II dilakukan pemilihan rumah tangga (responden) dengan cara pada setiap klaster terpilih ditentukan titik pusat secara acak, kemudian responden dipilih mulai dari rumah tangga yang ada orang dewasa ( $\geq 18$ tahun) dan terdekat dengan titik pusat. Selanjutnya berpindah ke rumah tangga berikutnya mengikuti arah jarum jam mengelilingi titik pusat, sampai didapat \pm 30 responden.

Dari 30 responden per klaster berarti terdapat 900 responden/kota sebagai unit analisis dari Direktorat BGM Depkes RI. Untuk penelitian ini diambil subsampel sebanyak 3-4 responden/klaster/kota. Menurut formula Lemeshow \& Hosmer (1989) didapat jumlah sampel 493 orang. Data diolah dengan menggunakan SPSSWIN.

Analisis statistik yang dilakukan meliputi:

1. analisis univariat, yaitu menjelaskan distribusi responden berdasarkan masing-masing variabel secara tunggal.

2. analisis bivariat, yaitu menjelaskan distribusi responden dari dua variabel yang dilihat hubungannya baik secara crosstab maupun korelasi.

3. analisis multivariat, yaitu menjelaskan berbagai variabel independen yang dilihat secara bersama-sama hubungannya dengan variabel dependen, berdasarkan analisis regresi linear berganda.

Dalam penelitian ini sebagai variabel dependen adalah kadar kolesterol serum, sedangkan variabel independennya adalah ukuran skinfold, umur, jenis kelamin, suku bangsa, indeks aktivitas, dan kebiasaan merokok.

\section{HASIL DAN PEMBAHASAN}

\section{Gambaran Umum Responden}

Setelah dilakukan pembersihan data, jumlah responden yang pantas diikutsertakan untuk analisis penelitian ini sejumlah 493 orang (laki-laki $=170$ orang dan perempuan $=323$ orang). Sebaran responden dalam persen berdasarkan umur, jenis kelamin,suku bangsa,indeks aktivitas dan kebiasaan merokok, ukuran skinfold dan kadar kolesterol serum dapat dilihat pada Tabel 1.

Hasil analisis data memperlihatkan bahwa rata-rata umur dan indeks aktivitas berdasarkan jenis kelamin masing-masing adalah 50,57 tahun dan 7,25 untuk laki-laki. Sedangkan rata-rata umur dan indeks aktivitas untuk perempuan adalah 43,72 tahun dan 6.75 . Distribusi responden menurut strata umur sebagian besar $\geq 50$ tahun , 20\% berumur antara 18 - 19 tahun, sementara $30 \%$ sisanya 
berumur 30 - 49 tahun. Secara keseluruhan terlihat bahwa jenis kelamin laki-laki proporsinya lebih rendah daripada perempuan, kecuali yang berumur $>60$ tahun.

Tabel 1. Distribusi Responden Berdasarkan Jenis Kelamin, Umur, Suku Bangsa,Indeks Aktivitas,Kebiasaan Merokok, Ukuran Skinfold, dan Kadar Kolesterol Serum (\%)

\begin{tabular}{|c|c|c|c|}
\hline Variabel & Laki-laki & Perempuan & Gabungan \\
\hline \multicolumn{4}{|l|}{ Umur (tahun) } \\
\hline $18-29$ & 16,25 & 24,80 & 22,11 \\
\hline $30-39$ & 9,08 & 15,57 & 13,53 \\
\hline $40-49$ & 16,77 & 19,39 & 18,57 \\
\hline $50-59$ & 17,39 & 20,20 & 19,32 \\
\hline $60-76$ & 40,51 & 20,03 & 26,46 \\
\hline \multicolumn{4}{|l|}{ Suku Bangsa } \\
\hline Batak & 6,34 & 17,60 & 14,07 \\
\hline Minangkabau & 8,20 & 14,29 & 12,38 \\
\hline Sunda & 32,99 & 21,97 & 25,43 \\
\hline Jawa & 23,80 & 16,59 & 18,85 \\
\hline Bali & 10,41 & 2,62 & 5,20 \\
\hline Bugis & 5,38 & 5,38 & 5,38 \\
\hline Lain-lain & 12,88 & 21,35 & 18,69 \\
\hline \multicolumn{4}{|l|}{ Indeks Aktivitas } \\
\hline$\leq 7,5$ (ringan) & 61,77 & 80,53 & 74,64 \\
\hline $7,6-10,5$ (sedang) & 37,16 & 19,47 & 25,03 \\
\hline$\geq 10,5$ (berat) & 1,07 & 0,0 & 0,33 \\
\hline \multicolumn{4}{|l|}{ Kebiasaan Merokok } \\
\hline Tidak Merokok & 45,07 & 93,32 & 78,17 \\
\hline Merokok & 54,93 & 6,68 & 21,83 \\
\hline \multicolumn{4}{|l|}{ Skinfold (mm) } \\
\hline Kuintil 1 (16,00 - 30,59 mm) & 7,32 & 7,84 & 10,82 \\
\hline Kuintil 2 (30,60 - 60,59 mm) & 49,19 & 42,75 & 44,77 \\
\hline Kuintil $3 \quad(60,60-90,59 \mathrm{~mm})$ & 19,82 & 31,54 & 27,86 \\
\hline Kuintil $4 \quad(90,60-120,59 \mathrm{~mm})$ & 12,74 & 13,62 & 13,34 \\
\hline Kuintil $5(120,60-155,59 \mathrm{~mm})$ & 0,93 & 4,25 & 3,21 \\
\hline \multicolumn{4}{|l|}{ Kadar Kolesterol Serum } \\
\hline$<200 \mathrm{mg} / \mathrm{dl}$ & 65,64 & 53,65 & 57,42 \\
\hline $200-239 \mathrm{mg} / \mathrm{dl}$ & 21,10 & 29,90 & 27,14 \\
\hline$\geq 240 \mathrm{mg} / \mathrm{dl}$ & 13,26 & 16,45 & 15,44 \\
\hline
\end{tabular}

Distribusi responden sebagian besar $(25,43 \%)$ berasal dari suku Sunda, yang diikuti secara berurutan yaitu suku Jawa (18,85\%), Batak (14,07 \%), Minangkabau (12,38 \%), Bugis (5,38\%) dan terkecil adalah Bali (5,20\%). Untuk indeks aktivitas, proporsi laki-laki dengan tingkat aktivitas ringan lebih kecil dibandingkan perempuan, sedangkan pada tingkat aktivitas sedang, proporsi laki-laki lebih banyak dari perempuan. Keadaan ini menunjukkan bahwa responden laki-laki lebih aktif dibandingkan perempuan. Untuk kebiasaan merokok, pada responden laki-laki (54,93\%) mempunyai kebiasaan merokok, jauh lebih banyak dari responden perempuan yang hanya kurang dari sepersepuluhnya (6.68\%). Data pada Tabel 1 memperlihatkan juga bahwa rata-rata skinfold responden adalah $61,70 \mathrm{~mm}$. Pada responden laki-laki rata-rata skinfold adalah 54,82 mm, sedangkan pada perempuan rata-rata $64,85 \mathrm{~mm}$. Karena belum adanya klasifikasi standar tentang pengukuran skinfold maka variabel skinfold dikategorikan menjadi 5 kelas (kuintil) (Garn, 1991) 
seperti disajikan pada Tabel 1. Proporsi antar kuintil cukup bervariasi. Untuk kedua jenis kelamin secara keseluruhan persentase skinfold tertinggi dijumpai pada kuintil 2. Pada laki-laki proporsi skinfold di kuintil 3, 4, dan 5 lebih rendah daripada perempuan, sedangkan pada kuintil 2 sebaliknya. Fenomena yang menarik adalah proporsi yang hampir sama untuk kedua jenis kelamin dan gabungan pada kuintil 4 . Adanya kecenderungan proporsi perempuan lebih besar pada kuintil 3 dan berikutnya dapat terjadi karena secara fisiologis perempuan mendeposit lemak sebagian besar pada bagian-bagian biceps, triceps, subscapular, dan suprailiac.

Sementara itu data di atas menunjukkan rata-rata kolesterol responden 195,883 mg/dl. Menurut jenis kelamin kadar kolesterol rata-rata pada perempuan adalah 197,95 mg/dl, sedangkan pada laki-laki 191,19 mg/dl. Berdasarkan klasifikasi yang disusun oleh PERKI (Kalim, Harmani, Santoso, \& Soerianata, 1996) kadar kolesterol serum dikategorikan menjadi 3 kelas, yaitu: ideal (< $200 \mathrm{mg} / \mathrm{dl}$ ); batas tinggi (200 - $239 \mathrm{mg} / \mathrm{dl}$ ); dan tinggi (hiperkolesterolemia: $\geq 240 \mathrm{mg} / \mathrm{dl}$ ). Pada penelitian ini ditemukan 57,42\% responden termasuk kelompok kadar kolesterol ideal, 27,14\% kelompok dengan batas tinggi dan kelompok hiperkolesterolemia sebesar 15,44\%.

Bila dipilah menurut jenis kelamin ternyata kadar kolesterol serum $\geq 200 \mathrm{mg} / \mathrm{dl}$ pada perempuan (46,53\%) lebih tinggi dibandingkan laki-laki (34,36\%). Sebaliknya kadar kolesterol ideal lebih banyak ditemukan pada laki-laki $(65,64 \%)$ dibandingkan perempuan $(53,65 \%)$.

\section{Ukuran Skinfold Berdasarkan Karakteristik Responden}

Proporsi responden berdasarkan skinfold dan karakteristik responden dapat dilihat pada

Tabel 2. Data tersebut menunjukkan bahwa secara keseluruhan proporsi tertinggi dijumpai pada responden dengan skinfold 30,60 - 60,59 mm (kuintil 2), kemudian diikuti dengan kuintil $3(60,60$ $90,59 \mathrm{~mm})$, sedangkan kuintil $1(16,00-30,59 \mathrm{~mm})$ dan kuintil $4(90,60-120,59 \mathrm{~mm})$ bervariasi, dan yang terkecil adalah proporsi responden pada kuintil 5 (120,60 - 155,59 mm).

Ditinjau dari variabel jenis kelamin, pada proporsi perempuan dengan skinfold $\geq 60,60 \mathrm{~mm}$ hampir satu setengah kali lipat $(49,41 \%)$ dari proporsi responden laki-laki $(33,49 \%)$. Hal sebaliknya terjadi pada proporsi laki-laki dengan skinfold $\leq 60,59 \mathrm{~mm}$, lebih besar dari proporsi perempuan. Dari variabel kelompok umur, responden dengan skinfold $\leq 30,59 \mathrm{~mm}$, proporsi tertinggi ditemukan pada kelompok umur 40 - 49 tahun (15,25\%), sedangkan terendah pada kelompok umur 30 - 39 tahun $(2,19 \%)$. Sebaliknya responden yang mempunyai skinfold $\geq 90,60 \mathrm{~mm}$ proporsi terendah dijumpai pada kelompok umur 40 - 49 tahun (8,91\%), sedangkan yang tertinggi ditemukan pada kelompok umur 30 - 39 tahun $(24,94 \%)$, dan berikutnya adalah kelompok umur $\geq 50$ tahun.

Jika dilihat dari variabel sukubangsa, responden dengan skinfold $\leq 30,59 \mathrm{~mm}$ proporsi tertinggi ditemukan pada suku Bali $(31,43 \%)$ dan terendah kecuali suku lain-lain adalah suku Bugis (6,98\%). Sementara itu responden dengan skinfold 30,60 - 60,59 mm proporsi tertinggi adalah suku Batak (50,43\%) dan terendah suku Sunda (38,99\%), sebaliknya pada skinfold 60,60 - 90,59 mm proporsi tertinggi pada suku Sunda (38,31\%) dan terendah pada suku Batak (14,16\%). Untuk skinfold $\geq 90,60$ mm didominasi oleh suku Jawa dan Batak, sedangkan terendah adalah suku Bali. Dengan demikian responden dari suku bangsa Bali mempunyai skinfold $\leq 90,59 \mathrm{~mm}$ hampir mencapai $95 \%$.

Bila ditelusuri dari kebiasaan merokok, responden yang tidak merokok proporsi skinfold $\leq$ $30,59 \mathrm{~mm}$ lebih rendah dibandingkan dengan responden yang merokok. Proporsi skinfold $\geq 90,60$ $\mathrm{mm}$ pada responden yang tidak merokok lebih kecil dari yang merokok masing-masing $15,73 \%$ dan $19,49 \%$. Ada kecenderungan responden yang merokok mempunyai skinfold yang lebih rendah dari responden yang tidak merokok. Menurut tingkat aktivitas fisik, terlihat proporsi responden dengan skinfold $\leq 30,59 \mathrm{~mm}$ lebih banyak ditemukan pada responden dengan aktivitas sedang dan berat. 
Untuk skinfold $\geq 90,60 \mathrm{~mm}$ pada responden dengan aktivitas ringan lebih kecil sedikit dari responden dengan aktivitas sedang/berat, masing-masing 16,05\% dan 18,28\%. Ada kecenderungan responden dengan aktivitas sedang dan berat mempunyai skinfold yang lebih rendah.

Tabel 2. Distribusi Responden Berdasarkan Skinfold dan Karakteristik Responden (persen)

\begin{tabular}{|c|c|c|c|c|c|c|}
\hline \multirow{2}{*}{ Variabel } & \multirow{2}{*}{ Kategori } & \multicolumn{5}{|c|}{ Skinfold (Kuintil - mm) } \\
\hline & & 1 & 2 & 3 & 4 & 5 \\
\hline \multirow[t]{2}{*}{ Jenis Kelamin } & Laki-laki & 17,32 & 49,19 & 19,82 & 12,74 & 0,93 \\
\hline & Perempuan & 7,80 & 42,75 & 31,54 & 13,62 & 4,25 \\
\hline \multirow[t]{5}{*}{ Umur (tahun) } & $18-29$ & 11,35 & 55,13 & 17,91 & 8,86 & 6,75 \\
\hline & $30-39$ & 2,19 & 29,98 & 42,89 & 20,78 & 4,16 \\
\hline & $40-49$ & 15,25 & 46,15 & 29,69 & 8,91 & 0,00 \\
\hline & $50-59$ & 7,64 & 41,38 & 29,19 & 18,72 & 3,07 \\
\hline & $60-74$ & 14,00 & 45,19 & 26,22 & 12,47 & 2,12 \\
\hline \multirow[t]{7}{*}{ Suku Bangsa } & Batak & 14,16 & 50,43 & 14,16 & 14,16 & 7,08 \\
\hline & Minang & 13,75 & 44,60 & 29,86 & 9,82 & 1,96 \\
\hline & Sunda & 9,89 & 38,99 & 38,31 & 10,48 & 2,33 \\
\hline & Jawa & 9,22 & 45,31 & 26,62 & 16,52 & 2,34 \\
\hline & Bali & 31,43 & 48,57 & 14,29 & 5,71 & 0,00 \\
\hline & Bugis & 6,98 & 47,64 & 34,91 & 3,49 & 6,98 \\
\hline & Lain-lain & 4,60 & 46,06 & 25,61 & 20,72 & 3,01 \\
\hline \multirow[t]{2}{*}{ Aktivitas } & Ringan & 10,69 & 45,64 & 27,63 & 13,67 & 2,38 \\
\hline & Sedang & 11,35 & 42,79 & 27,58 & 12,54 & 5,74 \\
\hline \multirow[t]{2}{*}{ Merokok } & Tidak & 10,02 & 44,35 & 29,89 & 13,47 & 2,26 \\
\hline & Ya & 13,67 & 46,27 & 20,57 & 12,89 & 6,60 \\
\hline
\end{tabular}

\section{Kadar Kolesterol Berdasarkan Karakteristik Responden}

Secara keseluruhan, proporsi responden dengan kadar kolesterol $<200 \mathrm{mg} / \mathrm{dl}$ mencapai lebih dari setengahnya, yaitu berkisar antara 38,53 - 74,47\%; diikuti responden dengan kadar kolesterol 200 - $239 \mathrm{mg} / \mathrm{dl}(13,90-38,009 \%)$, dan responden dengan kadar kolesterol > $239 \mathrm{mg} / \mathrm{dl}$ $(2,86-34,26 \%)$. Selanjutnya pada Tabel 3 , dilihat dari jenis kelamin, proporsi perempuan pada kadar kolesterol > $239 \mathrm{mg} / \mathrm{dl}$ lebih tinggi $(16,45 \%)$ dari proporsi laki-laki $(13,26 \%)$. Begitu juga dengan responden yang mempunyai kadar kolesterol 200 - $239 \mathrm{mg} / \mathrm{dl}$ proporsi perempuan lebih banyak (29,90\%) dibandingkan dengan laki-laki $(21,10 \%)$. Sebaliknya kadar kolesterol $<200 \mathrm{mg} / \mathrm{dl}$, proporsi laki-laki lebih tinggi $(65,64 \%)$ daripada perempuan $(53,65 \%)$.

Ditinjau dari segi usia, ternyata responden dengan kadar kolesterol $>200 \mathrm{mg} / \mathrm{dl}$ didominasi oleh kelompok usia 50 - 59 tahun $(61,46 \%)$ dan yang terkecil adalah kelompok usia $40-49$ tahun(25,52\%).

Berdasarkan suku bangsa, tampak proporsi responden yang mempunyai kadar kolesterol 200 - 239 mg/dl paling banyak berasal dari suku Batak (29,19\%) dan Minangkabau (28,70\%), dan yang terendah adalah suku Sunda $(20,27 \%)$.Sedangkan responden dengan kadar kolesterol $>239$ $\mathrm{mg} / \mathrm{dl}$ secara berturut-turut tiga terbanyak adalah suku Minangkabau (24,55\%), Bugis $(20,94 \%)$ dan Jawa $(18,60 \%)$, sedangkan yang terkecil adalah suku Bali $(2,86 \%)$. Menurut tingkat aktivitas fisik tampak bahwa proporsi responden yang mempunyai aktivitas sedang dan berat pada kolesterol > $200 \mathrm{mg} / \mathrm{dl}$ lebih sedikit (33,40\%) daripada responden dengan aktivitas ringan (45,86\%). 
Tabel 3. Distribusi Responden Berdasarkan Kadar Kolesterol dan Karakteristik Responden (persen)

\begin{tabular}{lllcc}
\hline \multirow{2}{*}{ Variabel } & \multicolumn{2}{c}{ Kategori } & \multicolumn{3}{c}{ Kadar Kolesterol $(\mathrm{mg} / \mathrm{dl})$} \\
\cline { 3 - 5 } Jenis Kelamin & Laki-laki & 65,64 & $200-239$ & $>239$ \\
& Perempuan & 53,65 & 21,10 & 13,26 \\
Umur (tahun) & $18-29$ & 66,91 & 26,90 & 16,45 \\
& $30-39$ & 51,84 & 13,90 & 6,57 \\
& $40-49$ & 74,47 & 14,68 & 34,26 \\
& $50-59$ & 38,54 & 38,09 & 10,85 \\
\multirow{3}{*}{ Suku Bangsa } & $60-74$ & 54,15 & 35,17 & 23,37 \\
& Batak & 56,65 & 29,19 & 10,67 \\
& Minangkabau & 46,75 & 28,70 & 14,16 \\
& Sunda & 66,35 & 20,27 & 13,53 \\
& Jawa & 54,74 & 26,66 & 18,60 \\
& Bali & 74,28 & 22,86 & 2,86 \\
Aktivitas & Bugis & 55,85 & 23,21 & 20,94 \\
\multirow{3}{*}{ Merokok } & Lain-lain & 51,36 & 36,71 & 11,93 \\
& Ringan & 54,14 & 28,69 & 17,17 \\
& Sedang & 66,61 & 22,87 & 10,53 \\
& Tidak & 53,96 & 30,85 & 15,19 \\
& Ya & 69,79 & 13,85 & 16,36 \\
\hline
\end{tabular}

Berdasarkan pada kebiasaan merokok, proporsi responden dengan kadar kolesterol 200 $239 \mathrm{mg} / \mathrm{dl}$ lebih banyak pada responden yang tidak merokok (30,85\%) dibandingkan yang merokok $(13,85 \%)$. Sebaliknya proporsi responden dengan kadar kolesterol $>239 \mathrm{mg} / \mathrm{dl}$, lebih banyak terdapat pada mereka yang mempunyai kebiasaan merokok (16,36\%) dibandingkan yang tidak merokok $(15,19 \%)$. Begitu juga proporsi responden yang mempunyai kadar kolesterol ideal lebih banyak ditemukan pada mereka yang biasa merokok (69,79\%) daripada yang tidak merokok $(53,96 \%)$. Adanya temuan yang berbeda pada penelitian kali ini dengan penelitian sebelumnya, diduga karena pengkategorian yang menggabungkan semua responden yang pernah merokok/mempunyai kebiasaan merokok tanpa membedakan jumlah dan frekuensinya. Kemungkinan lain adalah jumlah rokok yang dihisap tidak terlalu banyak sehingga tidak berpengaruh terhadap kadar kolesterol serum.

\section{Distribusi Nilai Rata-rata Kadar Kolesterol Berdasarkan Karakteristik Responden dan Ukuran- ukuran Skinfold}

Secara keseluruhan rata-rata kadar kolesterol serum $(\mathrm{mg} / \mathrm{dl})$ berdasarkan karakter responden dan ukuran skinfold adalah sebagai berikut. Kadar kolesterol terbesar untuk masingmasing adalah responden dengan jenis kelamin perempuan (197,95 mg/dl), suku bangsa Minangkabau (213,25mg/dl), tidak mempunyai kebiasaan merokok (198,06 mg/dl), beraktivitas ringan (198,25 mg/dl), dan mempunyai skinfold 90,60 - 120,59 mm (211,08 mg/dl). Dari sekian banyak variabel prediktor yang diukur, kadar kolesterol rata-rata tertinggi terdapat pada responden dengan ciri memiliki skinfold $90,60-120,59 \mathrm{~mm}(211,08 \mathrm{mg} / \mathrm{d})$ ). Keadaan ini terjadi pada responden berumur 30 - 39 tahun, yang diduga pada ukuran skinfold tersebut faktor penyerapan dan penggunaan zat gizi yang masuk ke tubuh dalam keadaan optimal. Pada responden yang mempunyai kadar kolesterol 
rata-rata di atas $200 \mathrm{mg} / \mathrm{dl}$ (batas tinggi) di antaranya adalah mereka yang berumur 30 - 39 tahun dan 50 -59 tahun, berasal dari suku Minangkabau dan Bugis, serta mempunyai skinfold > 60,60 mm. Kecuali kategori tersebut tadi, semuanya termasuk ke dalam kelompok dengan kadar kolesterol ratarata ideal $(200 \mathrm{mg} / \mathrm{dl})$, sebagaimana terlihat pada Tabel 4.

Tabel 4. Nilai Rata-rata Kadar Kolesterol (mg/dl) Berdasarkan Karakteristik Responden dan Ukuran-ukuran Skinfold

\begin{tabular}{llc}
\hline \multicolumn{1}{c}{ Variabel } & \multicolumn{1}{c}{ Kategori } & Nilai Rata-rata Kolesterol $(\mathrm{mg} / \mathrm{dl})$ \\
\hline Jenis & Laki-laki & 191,19 \\
Kelamin & Perempuan & 197,95 \\
Umur & $18-29$ & 184,37 \\
(tahun) & $30-39$ & 206,46 \\
& $40-49$ & 183,74 \\
& $50-59$ & 213,16 \\
Suku & $60-74$ & 195,79 \\
Bangsa & Batak & 186,49 \\
& Minangkabau & 213,25 \\
& Sunda & 192,27 \\
& Jawa & 198,32 \\
& Bali & 174,33 \\
& Bugis & 202,6 \\
Aktivitas & Lain-lain & 197,68 \\
& Ringan & 198,25 \\
& Sedang & 18919 \\
Merokok & Berat & 153,18 \\
& Tidak & 198,06 \\
Skinfold & Ya & 187,82 \\
& $16,00-30,59$ & 179,44 \\
& $30,60-60,59$ & 188,36 \\
& $60,60-90,59$ & 206,35 \\
& $90,60-120,59$ & 211,08 \\
& $120,60-155,59$ & 200,37 \\
\hline
\end{tabular}

Rata-rata kolesterol serum orang dewasa yang berumur 18 - 74 tahun adalah 195,83 mg/dl. Hal ini menunjukkan bahwa rata-rata kolesterol responden tergolong ke dalam kelompok berkadar kolesterol normal (ideal) berdasarkan kategori PERKI (Kalim, Harmani, Santoso, \& Soerianata, 1996). Menurut jenis kelamin rata-rata kolesterol pada perempuan adalah $197,95 \mathrm{mg} / \mathrm{dl}$ yang lebih tinggi dibandingkan laki-laki yang sebesar $191,19 \mathrm{mg} / \mathrm{dl}$. Angka ini masih lebih rendah dari hasil studi WHO (1995) masing-masing sebesar 213 mg/dl pada perempuan dan 204 mg/dl pada laki-laki.

Secara keseluruhan responden yang tergolong berkadar kolesterol ideal sekitar 57,42\%, selebihnya yaitu $27,14 \%$ dan $15,44 \%$ masing-masing termasuk golongan dengan kadar kolesterol batas tinggi dan kadar kolesterol tinggi (hiperkolesterolemia). Berdasarkan jenis kelamin kadar kolesterol tinggi pada perempuan (16,45\%) lebih tinggi dibanding laki-laki $(13,26 \%)$. Namun demikian hasil di atas masih lebih rendah bila dibandingkan dengan hasil penelitian WHO (1995) yang masing-masing sebesar $17,0 \%$ dan 15,2\%. Walaupun tidak terlalu tinggi proporsinya, responden dengan kadar kolesterol tinggi ( $\geq 240 \mathrm{mg} / \mathrm{dl}$ ) perlu dicermati, karena hiperkolesterolemia merupakan 
salah satu faktor risiko penyakit jantung koroner, yang merupakan penyakit peringkat pertama di Indonesia pada masyarakat di atas 35 tahun (Depkes RI, 1997). Khusus mengenai gambaran tentang nilai rata-rata kadar kolesterol pada berbagai ukuran skinfold, secara diagramatis dapat dilihat pada Gambar 3.

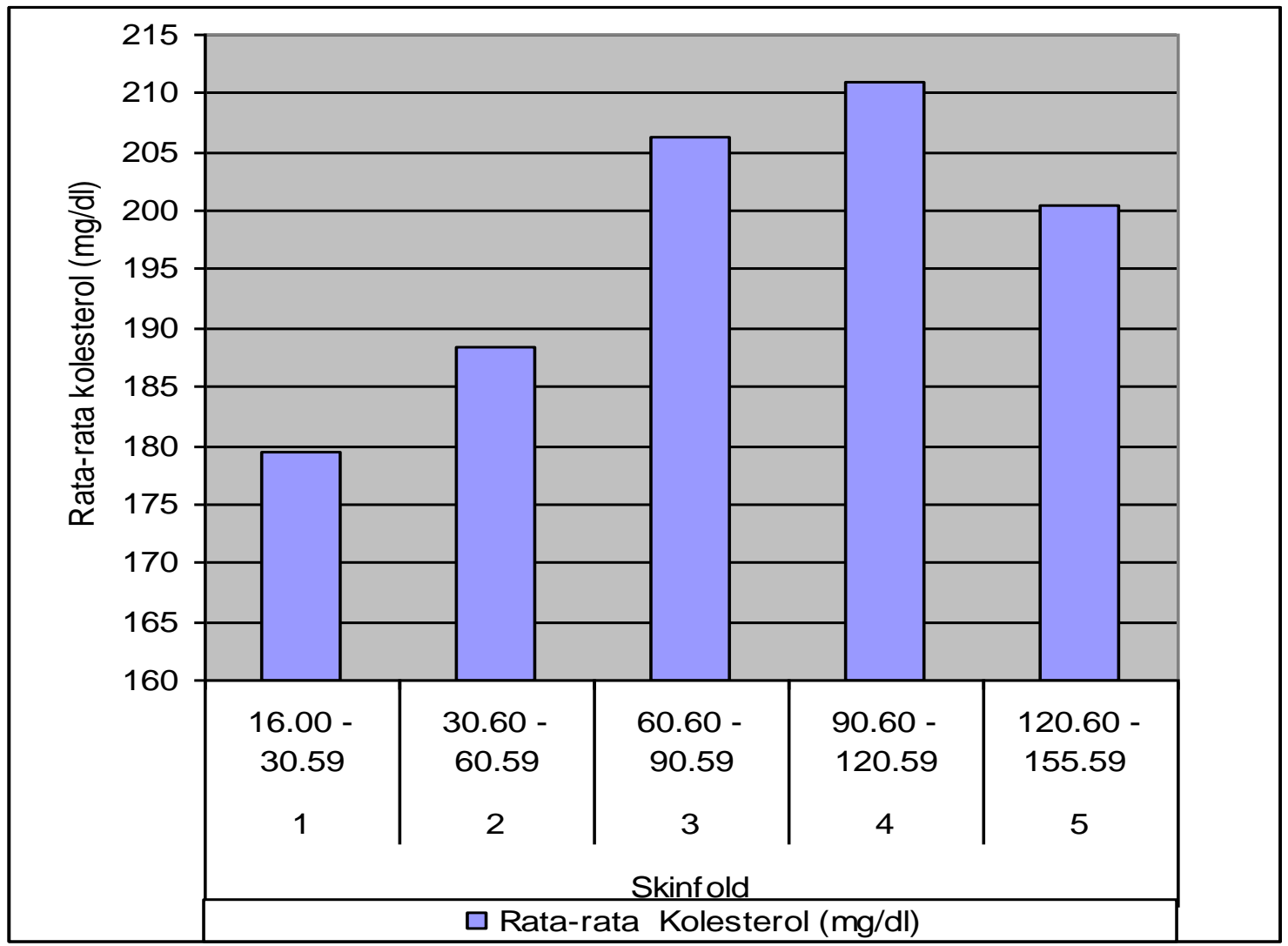

Gambar 1. Distribusi Rata-rata Kolesterol Berdasarkan Ukuran Skinfold

\section{Kolesterol dan Skinfold}

Proporsi responden dengan kadar kolesterol $<200 \mathrm{mg} / \mathrm{dl}$ terbanyak dijumpai pada mereka yang mempunyai ukuran skinfold 16,00 - 30,59 mm (66,29\%), terkecil ditemukan pada responden dengan ukuran skinfold 90,60 - 120,59 mm (47,84\%). Sebaliknya proporsi responden yang mempunyai kadar kolesterol > 239 mg/dl terbanyak pada mereka dengan skinfold 120,0 - 155,59 $\mathrm{mm}(32,63 \%)$, dan terkecil pada responden dengan skinfold 16,0 - 30,59 mm (6,74\%). Sedangkan proporsi responden yang mempunyai kadar kolesterol 200 - $239 \mathrm{mg} / \mathrm{dl}$ terbanyak ditemukan pada responden dengan skinfold 60,60 - 90,59 $\mathrm{mm}(28,50 \%)$, dan terkecil pada responden dengan ukuran skinfold 120,0 - 155,59 mm (14,24\%). Ada kecenderungan meningkatnya skinfold diikuti dengan meningkatnya kadar kolesterol. 


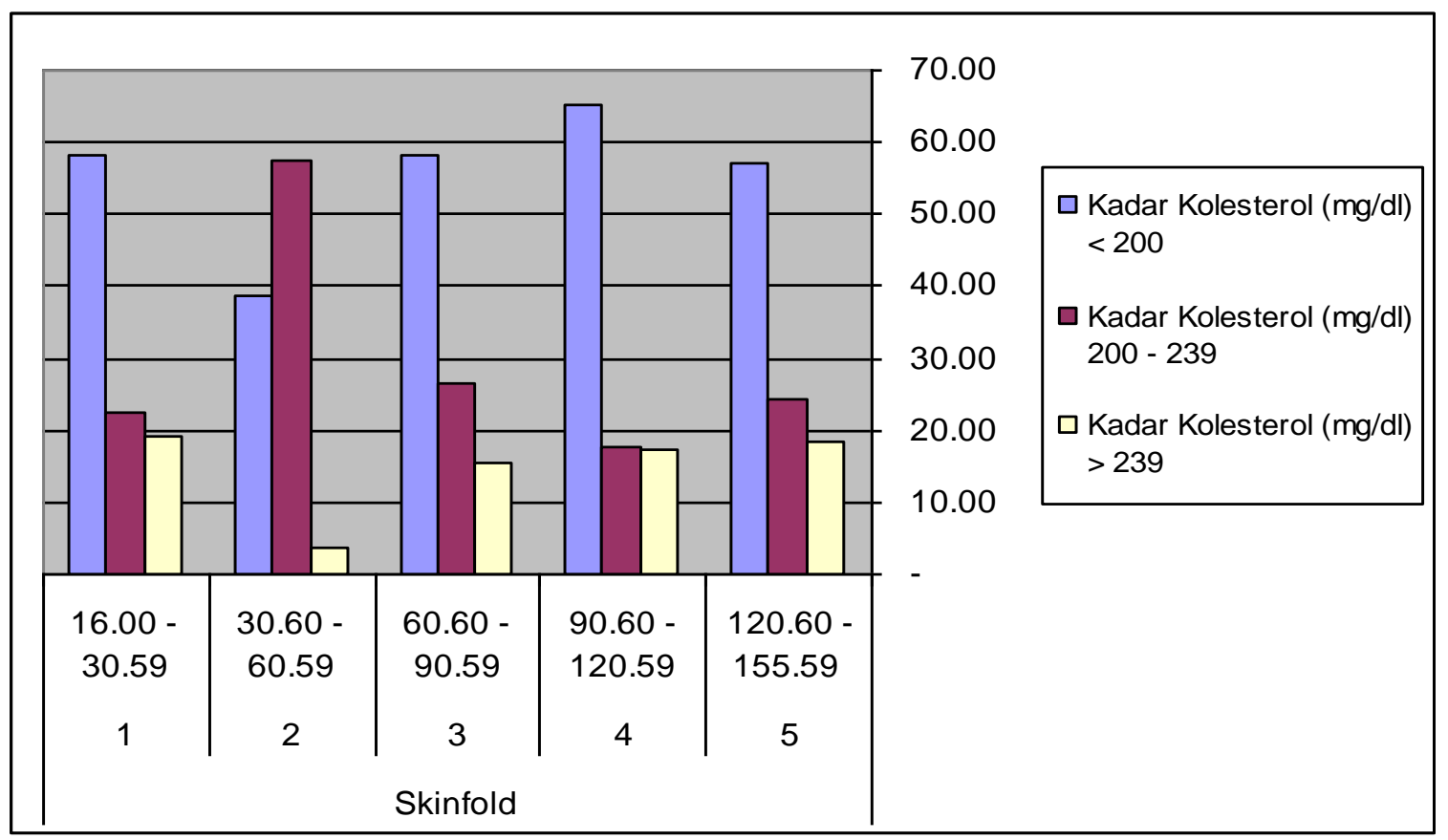

Gambar 2. Distribusi Responden Berdasarkan Kadar Kolesterol dan Skinfold (persen)

\section{Hubungan Antar Variabel Konfounder}

Tabel 5. menggambarkan hubungan antar variabel yang terdapat dalam konfounder (karakteristik responden) yaitu antar variabel umur, jenis kelamin, aktivitas, suku bangsa dan kebiasaan merokok. Secara keseluruhan terdapat hubungan yang positif antara umur dengan aktivitas $(0.13$ pada $p<0,05)$ dan jenis kelamin $(0.20$ pada $p<0,01)$, antara jenis kelamin dengan aktivitas $(0.20$ pada $p<0,01)$ dan kebiasaan merokok $(0.54$ pada $p<0,001)$, dan antara kebiasaan merokok dengan suku bangsa $(0.62$ pada $p<0,001)$.

Pada Tabel 6 ditunjukkan hubungan antara variabel prediktor (independen) yang meliputi variabel skinfold, umur, jenis kelamin, aktivitas, suku bangsa dan kebiasaan merokok dengan variabel dependen dalam hal ini adalah kolesterol serum. Tampak hubungan positif bermakna antara varibel kolesterol dengan skinfold ( $p<0,01)$, kolesterol dengan umur $(p<0,01)$, kolesterol dengan suku bangsa (Minangkabau) dengan $p<0,01$.

Tabel 5. Matrik Korelasi Antar Variabel Konfounder

\begin{tabular}{lccccc}
\hline \multicolumn{1}{c}{ Kriteria } & Umur & Aktivitas & Jenis Kelamin & Suku Bangsa & Kebiasaan Merokok \\
\hline Umur & 1,00 & $0,13^{*}$ & $0,20^{* *}$ & 0,26 & 0,08 \\
Aktivitas & $0,13^{*}$ & 1,00 & $0,20^{* *}$ & 0,13 & 0,10 \\
Jenis Kelamin & $0,20^{* *}$ & $0,20^{* *}$ & 1,00 & 0,26 & $0,54^{* * *}$ \\
Suku Bangsa & 0,26 & 0,13 & 0,26 & 1,00 & $0,62^{* * *}$ \\
Kebiasaan Merokok & 0,08 & 0,10 & $0,54^{* *}$ & $0,62^{* * *}$ & 1,00 \\
\hline
\end{tabular}

\footnotetext{
* $\quad p<0,05$

** $\quad p<0,01$

$* * * \quad p<0,001$
} 
Tabel 6. Matrik Korelasi Antar Variabel Konfounder dengan Skinfold dan Kolesterol

\begin{tabular}{lcc}
\hline \multicolumn{1}{c}{ Kriteria } & Skinfold & Kolesterol \\
\hline Umur & 0,04 & $0,12^{* *}$ \\
Aktivitas & 0,04 & $-0,08$ \\
Jenis Kelamin & $-0,17^{*}$ & $-0,07$ \\
Suku Bangsa & 0,16 & $0,20^{* *}$ \\
Kebiasaan Merokok & 0,02 & $-0,10$ \\
Skinfold & 1,00 & - \\
Kolesterol & $0,23^{* *}$ & 1,00 \\
\hline
\end{tabular}

* $p<0,05$

** $p<0,01$

Sedangkan antara kolesterol dengan jenis kelamin $(p<0,15)$, dengan aktivitas $(p<0,15)$, dengan kebiasaan merokok $(p<0,15)$ ketiganya terdapat hubungan negatif, namun tidak bermakna untuk $p<0,05$. Artinya responden laki-laki mempunyai kadar kolesterol lebih rendah daripada perempuan. Semakin aktif seseorang, maka kadar kolesterol akan menurun. Pada perokok tidak dijumpai hubungan antara kadar kolesterol dengan kegiatan merokok. Sementara itu terlihat pula bahwa skinfold mempunyai hubungan negatif bermakna dengan jenis kelamin $(p<0,01)$, sedangkan suku bangsa dan skinfold paling bermakna dengan kolesterol.

\section{Pendugaan Kadar Kolesterol Serum}

Analisis regresi linear berganda dilakukan untuk mengetahui sejauh mana hubungan antara variabel dependen (kadar kolesterol serum) dengan sekelompok variabel independen (prediktor) yang ada pada penelitian ini. Dalam hal ini skinfold sebagai variabel utama, dan selebihnya yaitu karakteristik responden merupakan konfounder (umur, jenis kelamin, suku bangsa, indeks aktivitas, kebiasaan merokok). Keluaran dari analisis ini adalah terbentuknya suatu model dalam rangka memprediksi variabel dependen yaitu kadar kolesterol serum.

Sebenarnya variabel jenis kelamin mempunyai nilai $p>0,05$, namun karena pertimbangan substansi variabel jenis kelamin tetap dimasukkan ke dalam model. Penilaian prediktor dan konfounder ini dilakukan dengan melihat besarnya perubahan koefisien determinasi dan koefisien regresi skinfold. Model yang mempunyai selang kepercayaan $(\mathrm{Cl})$ koefisien regresi skinfold yang sempit (menunjukkan presisi yang lebih tinggi) dan pertimbangan substansi dipilih sebagai model terbaik. Pada akhir penilaian,variabel yang tetap bertahan dalam model adalah : skinfold, umur, jenis kelamin, aktivitas, dan suku bangsa.

Hasil akhir dari proses pemodelan, dapat diajukan model terbaik yaitu:

$$
\begin{aligned}
& K K S=153,58+0,36 S+0,34 U-1,46 K-48,71 A+27,84 B \\
& \text { di mana, KKS : Kadar Kolesterol Serum } \\
& \text { S : Skinfold } \\
& \text { U : Umur } \\
& \mathrm{K} \text { : Jenis Kelamin } \\
& \text { A : Aktivitas } \\
& \text { B : Sukubangsa }
\end{aligned}
$$


Koefisien determinasi dari model ini (R-kuadrat $=12,63 \%)$; artinya model hanya dapat menerangkan besarnya keragaman variasi variabel kolesterol sebesar $12,63 \%$, selebihnya diterangkan oleh variabel lain yang belum tercakup dalam penelitian ini.

Berdasarkan hasil analisis regresi linear berganda, responden dengan tingkat aktivitas berat dan sedang mempunyai kadar kolesterol masing-masing lebih rendah 48,71 mg/dl dan 9,56 mg/dl dibanding responden dengan aktivitas rendah. Demikian pula jenis kelamin laki-laki mempunyai kadar kolesterol lebih rendah 1,46 mg/dl dibanding dengan perempuan. Sedangkan pada suku Minangkabau mempunyai kadar kolesterol lebih tinggi 27,84 mg/dl dibanding suku Batak. Suku Bali mempunyai kadar kolesterol lebih rendah 4,31 mg/dl dibanding suku Batak, sedangkan suku-suku lainnya secara berurutan adalah suku Sunda, Jawa, Bugis dan lainnya (campuran) mempunyai kadar kolestrerol masing-masing 3,4 mg/dl, 8,07 mg/dl, 16,67 mg/dl dan 9,19 mg/dl lebih tinggi dibandingkan suku Batak.

\section{KESIMPULAN}

1. Secara keseluruhan dari sampel orang dewasa ( $\geq 18$ tahun) di enam kota di Indonesia ditemukan sebanyak 15,44\% orang dewasa tergolong hiperkolesterol dan 27,14\% termasuk kadar kolesterol batas tinggi (200 - $239 \mathrm{mg} / \mathrm{dl})$. Menurut jenis kelamin, laki-laki yang termasuk hiperkolesterolemia adalah $13,26 \%$ dan perempuan adalah 16,45\%. Berdasarkan umur, persentase tertinggi yang tergolong hiperkolesterolemia adalah kelompok umur 30-39 tahun $(34,26 \%)$, suku bangsa Minangkabau (24,55\%), responden dengan aktivitas ringan $(17,17 \%)$ dan mempunyai kebiasaan merokok (16,36 \%).

2. Ukuran skinfold tinggi (kuintil 4 dan 5) menurut jenis kelamin ditemukan pada $13,67 \%$ responden laki-laki dan $17,87 \%$ responden perempuan.

3. Dari hasil analisis bivariat terdapat hubungan yang bermakna antara kolesterol dengan skinfold, umur, dan suku bangsa $(p<0,01)$ yaitu dengan meningkatnya ukuran skinfold dan umur meningkat pula kadar kolesterol serum orang dewasa.

4. Kadar kolesterol serum dapat diprediksi dengan persamaan regresi sebagai berikut: Kadar Kolesterol Serum $=153,58+0,36$ Skinfold + 0,34 Umur $-1,46$ Jenis Kelamin $-48,71$ Aktivitas $+27,84$ Sukubangsa

Bila dilihat pengaruh masing-masing variabel prediktor terhadap kadar kolesterol, tampak bahwa dengan dikontrol variabel umur, aktivitas, suku bangsa, dan jenis kelamin setiap peningkatan skinfold $1 \mathrm{~mm}$ dapat meningkatkan kadar kolesterol sekitar $0.36 \mathrm{mg} / \mathrm{dl}$. Bila diketahui ukuran variabel untuk masing-masing prediktor maka kadar kolesterol dapat didekati dengan model di atas, sehingga dapat dilakukan secara massal dan dengan biaya lebih murah. Namun demikian, angka koefisien determinasi dari model tersebut sebesar $\mathrm{R}^{2}=12,63 \%$; artinya model hanya dapat menerangkan besarnya keragaman variasi variabel kolesterol sebesar $12,63 \%$, selebihnya diterangkan oleh variabel lain yang belum tercakup dalam penelitian ini. Oleh karena itu, perlu penelitian lebih lanjut dengan melibatkan berbagai variabel yang dapat meningkatkan besaran koefisien determinasi model tersebut.

\section{REFERENSI}

Clifton, P. M., Abbey, M., Noakes, \& M. Beltrame, S. (1995). Body fat distribution is a determinant of the high-density lipoprotein response to dietary fat and cholesterol in women. American Heart Association Inc. 
Cooper, G. R., Myers, G., Smith, J., \& Schlant, R. C. (1992). Blood lipid measurements. Variation and practical utility, dalam Journal of the American Medical, 267 (12), 1652 - 1660.

Departemen Kesehatan Republik Indonesia. (1997). Survei Kesehatan Rumah Tangga. Jakarta: Pusat Data Kesehatan Departemen Kesehatan Republik Indonesia.

Garn, S. M. (1991). Implications and applications of subcutaneus fat measurement to nutritional assessment and health risk evaluation, dalam John $\mathrm{H}$. Himes (ed.). Anthropometric assessment of nutritional status. USA: Willey-Liss, Inc.

Hakim, I. A., Amina, H., Mohammed, Nagwa, H., \& El-Jusseiny. (1997). Blood cholesterol and triglycerides in adolescent egyptian girls: Relation to anthropometric measurements. Food and Nutrition Bulletin, 18 (1), 56 - 63.

Kalim, Harmani, Santoso, K., \& Soerianata, S. (1996). Pedoman tatalaksana dislipidemia dalam penanggulangan penyakit jantung koroner. Jakarta: Persatuan Dokter Spesialis Kardiovaskuler Indonesia.

Lemeshow, S, \& Hosmer, D. W. (1989). Applied logistic regression. USA: A Whiley-Interscience Publication.

Seidell, J. C., Cigolini, M., Charzweska, J., \& Ellsinger B. M. (1990). Fat distribution in European Women: A comparison of antropometric Measurements in relation to cardiovascular Risk Factors. International Journal of Epidemiology. 19 (2), 303 - 308.

WHO. (1995). Physical status: The use and interpretation of anthropometry. WHO Technical Series 854, Geneve. 452 hal.

Wynder, E. L., Field, F., \& Haley, N. J. (1986). Population screening for cholesterol determination. A pilot study. Journal of the American Medical, 256 (20), 2839-2842. 